by Peter Laznicka

\title{
Knowledge systems based on miniaturized geological samples: Lithotheque and Data Metallogenica, a proposal for international adoption
}

\author{
Metallogenica Consulting, Adelaide, Australia.E-mail: plaznicka@dodo.com.au
}

In the electronic age, traditional collections of geological specimens as in museums, and bulky materials as in drill core "libraries", lag behind the general progress as they require more space to keep and labour to maintain. This results in liquidation of some established collections and near-sequestration of others so that physical access to material for study and research is severely restricted. This is countered by the growth of virtual collections of electronic images. Miniaturization of rock and ore samples that are then attached to rigid plates in fixed order and the plates held in stacks like books for instant access can alleviate this problem. Lithotheque, a rock library, and its outgrowth Data Metallogenica, are mature systems with a 40 years long history that store information about mineral deposits of the world based on representative miniaturized rock and ore sample sets. They are presented as both images on internet and a "hands-on" resource in office; the latter can be visually compared and non-destructively tested. Lithotheque and Data Metallogenica serve as rapid abstracts keeping permanent geological record not influenced by the change of genetic ideas, as a visual standard in mineral exploration, and as advanced educational tool. Because Lithotheque is so cheap to establish, exchange and maintain in a very limited space, it is proposed that the methodology be adopted internationally. A credible and permanent record in support of global metallogeny (and many other disciplines in Earth sciences) could be achieved by pooling together information contributed by many local (national) centres using the same methodology.

\section{Introduction}

Collections and repositories of geological materials (rocks, minerals, partly soils and liquids) have a hard time adjusting to realities of the present rushed life and exponential growth. Classical institutional collections of geological materials as in public museums, universities and geological surveys (as opposed to private specimens collections held as investment) suffer from lack of space and high labor costs of upkeep. Even in the best funded museums only a fraction of total holdings is displayed and/or is relatively easily accessible for study and research in drawers, whereas the bulk is stored in depositories or packed. As a result, access is difficult or virtually impossible for most, except a handful of mainly internal researchers. In the past decades several important institutional collections have been liquidated: sold, dispersed, put into dead storage, some outright discarded (Mikulic and Kluessendorf, 2002; National Academy of Sciences, 2002; Simpson, 2003). The remaining collections barely grow and in any case lag behind the rapidly increasing new, but temporary, sources of geological materials such as operating mines and technical excavations.

Drill core repositories (usually called, rather inaccurately, libraries), maintained by governments, have been a new form of storage of geological materials, around and growing since only the 1960s and 1970s. They are highly specialized, warehouse-style holdings, that store thousands of kilometers of drill core produced by the parent organization (typically a state geological survey) as well as contributed, voluntarily or by law, by the private exploration and geotechnical industries. In addition to drill core most "libraries" also store cuttings from rotary and impact drill holes; field documentation samples; and occasionally samples of ore and host rocks from mines. Most government core "libraries" are accessible to, and provide various services for, the professional public such as exploration geologists. Such services, in the West usually provided free (at government expense) or for a nominal charge, represent a valuable investment for future generations. Like the classical museums, however, core "libraries" rapidly run out of space especially in times of exploration booms, requiring new construction. The enhanced scope of services requires greater number of employees. These developments burden the host organization with accelerating costs, especially in times of budgetary constraints. These costs could be limited if long, monotonous, geologically uniform drill core intervals were culled resulting in reduction in the volume of material that has to be stored. Also helpful would be some means of rapid preview of the information available from an individual drill core that would enable preliminary browsing, so that a user might request deployment of only a limited amount of drill core rather than "all there is". Anecdotal evidence indicates that between $20 \%$ and $100 \%$ of drill core put on display, a time and labor consuming process, does not contain the information sought and could have been avoided. 
Modern electronic technology and organization somewhat alleviate record keeping, information searches, and material displays of geological collections. Keyword-based computerized databases are now a commonplace. Selected, or even entire, inventories of geological specimens in major museums and some teaching collections are now available on-line, in vivid color. Photographs of selected intervals of drill core, or even continuous photographic logs, are increasingly available on government websites (e.g. in the National Virtual Core Library of Australia; Mauger, 2008). Some include additional information about physical properties such as mineral spectra, specific gravity, magnetic susceptibility, radiometry as well as geochemistry and others. These are, however, all virtual characteristics available for remote viewing. They have not eliminated the need for hands-on study where the real samples could be directly observed, examined, compared and non-destructively custom-tested. Hundreds of geological collections around the world store and convey objective knowledge about various aspects of geosciences, but each uses different style and organization. This makes it extremely difficult to make comparisons and arrive at a global picture: for example, an assembly of sample suites from ore deposits of the presently popular IOCG type (=iron oxide-copper-gold; Hitzman et al., 1992) that could be uniformly visualized, compared and tested. Research community as well as mineral exploration industry would benefit from a uniformly organized database of world's mineral deposits and their environments supported by real geological materials that could be objectively examined, unencumbered by conceptual models of the day that keep changing. The sample sets on display should be of limited complexity in order not to overwhelm, yet carefully selected to present an objective "story" of a deposit. They should be the equivalent of abstracts to longer paper reports, and be available for physical inspection and on-line (electronic images) browsing. This type of a "rock library", Lithotheque, has been in existence since 1970. It has been continuously improved, thoroughly tested, and put to practical service. An outgrowth of a simple Lithotheque collection has been the multicomponental information and expert system Data Metallogenica, available online since 2002.

\section{Lithotheque, a rock library}

Lithotheque (from Greek) means "rock library". We gave this name to a collection and a style of arrangement of sets of miniaturized rock and ore samples that are, in systematic fashion, permanently attached (cemented) to rigid (originally cardboard, now aluminum) page-size plates that could be held, like books, in library-like stacks suitable for open browsing. Only recently I have discovered that the same name was also given by one Signor Riminaldi in Ferrara, Italy, to his $18^{\text {th }}$ century "stone archive" (Marrocchino et al., 2008). Another "stone archive" that includes over 5600 macro-samples $(24 \times 15 \times 2 \mathrm{~cm})$ of building and ornamental stones of the world is kept in the Deutsches Naturstein-Archiv in Wunsiedel, Germany. This collection is accessible to the public on-line (www.deutchesnatursteinarchiv.de) and on-site. More specialized collections of geological materials with a public access exist worldwide, but it is not the purpose of this paper to provide a directory.

The present Lithotheque originated in the Queensland bush in 1970 , as a means of keeping a systematic material record of localities visited during field reconnaissance of the "Tasman Geosyncline" by Peter and Sarka Laznicka, working for Australian Selection (Pty) Ltd.
The collection of some 70 cardboard Lithotheque plates of up to 20 samples each was assembled on the go and it provided an excellent factual basis for report compilation. It delighted the management as a credible base for specialist follow-up. A standard Lithotheque plate measures $7 \times 11$ inches $(=17.8 \times 28 \mathrm{~cm})$ and fits into a custom made $12 \times 12 \times 12$ in. $(=\sim 30.5 \mathrm{~cm})$ slotted wooden cube. The cubes, taking 20 plates each in either vertical or horizontal position, can be manipulated separately or assembled into a $1.8 \mathrm{~m}$ high storage wall. 3 linear meters of such a wall accommodate 1200 plates, that is up to 24,000 miniaturized samples. The space economy, cleanliness and instant accessibility are excellent, suitable for an office or a boardroom placement. The sample layout on each plate follows a typical progression: oxidized ores/rocks $\rightarrow$ ore varieties $\rightarrow$ alterations $\rightarrow$ host rocks $\rightarrow$ associated rocks. Localities (deposits) are represented by one or more plates of up to 20 mini-samples each. Alternative arrangements that include drill core slabs, oversize samples, etc. are possible (Fig. 1). Friable or powder-like samples are kept in transparent plastic "jewel boxes" cemented to the plate like the solid materials.

Each Lithotheque is accompanied by explanation sheet ("legend") that shows the position of numbered geological units in a simplified cross-section (or a map), and a table with brief description of each unit (Fig. 2). The actual samples are numbered on grid, or sequentially, and described in another table. Materials displayed in Lithotheque are organized by numbered rock units (from youngest to oldest), variety of mineralizations (M; M1, M2, etc. are hypogene ores, MW are oxidized ores, MS are resedimented ores), alterations (A; A1, A2 etc.) and their combinations (Fig.3). Whereas the samples incorporate permanent objective facts, the explanation sheets include interpretations and require update every few years. It has been found that miniaturized samples convey up to $80 \%$ of visual information about lithology normally available from the usual size geological samples with a dimension of $12 \mathrm{~cm}$ ( $\sim 5$ inches $)$ and more. Very coarse grained rocks like breccias and conglomerates or samples of ore structures can be represented by an overall photograph, the components of which, like clasts or fragments, are incorporated into the Lithotheque set. Sample miniaturization results in a substantial saving in space and weight: twenty typical Lithotheque samples are equivalent to one or two "standard" hand samples in weight and volume, yet they convey substantially more information, especially in terms of lithologic variability. Reduced sample weight and volume support portability and greatly reduce shipping costs making Lithotheque a "poor person's" style of geological collecting. The permanent attachment of samples to a board not only makes it possible to handle and store Lithotheques like books providing for superior portability and accessibility, but it preserves the order of sample arrangement, it prevents loss, and encourages the "reader" to consider the whole rather than to focus on a single sample taken out of a broader context. The obvious drawback is that one side of the sample remains permanently hidden. The impossibility of moving Lithotheque samples is compensated for by a parallel collection of selected hand samples called Macrotheque.

The original Lithotheque, as described above, serves as a permanent record of lithology and mineralogy of mineral deposits and of their host rock associations or environments. Such a record is particularly valuable for mines sampled during their working life that have been exhausted and their sites reclaimed so no more material is locally available and the factual record is lost. The same Lithotheque methodology can be used to record lithology of non-ore geological 

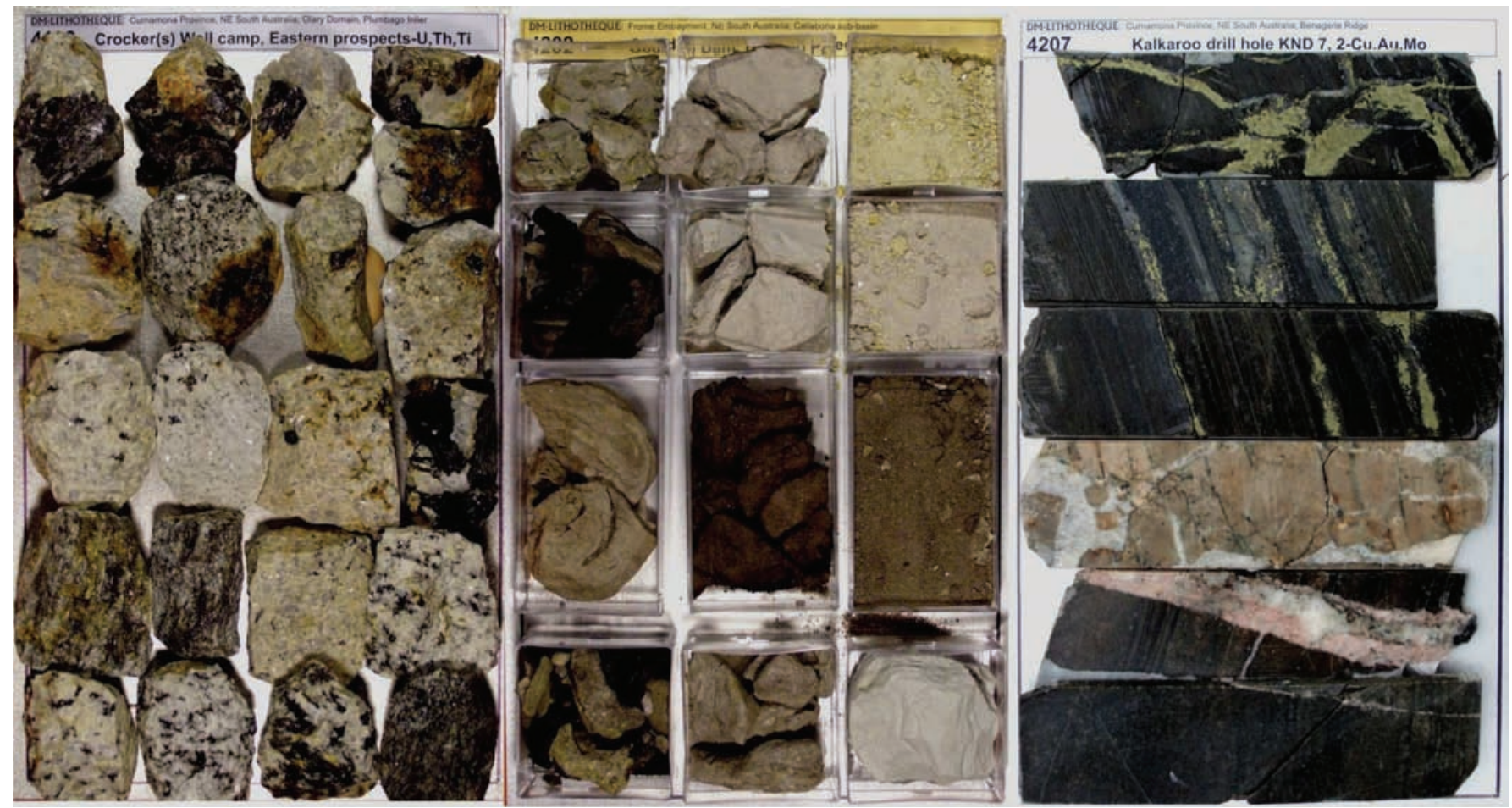

Figure 1. Lithotheque, alternative styles of arrangement of permanently attached miniaturized rock and ore samples on page-size aluminum plates. Left: a standard plate of up to 20 rigid samples; each sample measures about $5 x 4 \mathrm{~cm}$ and the plate can be stored in vertical position (Crockers Well-U, South Australia). Middle: friable, loose, powdery, clay-like samples are held in plastic transparent "jewel boxes" (Goulds Dam-U, South Australia). Right: outsize slabs cut from drill core (Kalkaroo Cu-Au, South Australia). In explanation sheets samples in the left plate are numbered on grid (left to right then down), samples in the middle and right plates are numbered sequentially.

localities like outcrops or excavations; to produce thematic sample sets representing the Munsell Color Scale; effects of increasing metamorphic grade on a uniform progenitor; alteration assemblages; grain roundness and angularity; textures and structures; porosity types; and others. Lithotheque can represent type localities and models (e.g. of ore deposits); hold material record of research projects in a permanent, organized fashion; provide a "live", testable database of physical properties of materials such as mineral spectra (PIMA; e.g. HyLogger, Keeling et al., 2004); X-ray tomography (Kyle and Ketcham, 2003); magnetic susceptibility and conductivity; radioactivity; it can accommodate international analytical standards; and others. The existing Lithotheques have been used, and can be used, for the following purposes: as a geological record to keep; as a visual standard for description (e.g. for drill core logging); as an educational resource (especially valuable for self-study or a small group study); as a component of databases and expert systems; as standard of physical properties of materials; and others.

\section{Lithotheque-based geological knowledge systems}

Once the Lithotheque collection under development at the University of Manitoba reached a critical size (1000 and more plates representing mineral deposits of the world), additional components have been added: both to the physical collection of geological samples, and to the original inventory database in MS-ACCESS. The result has been a multicomponental information system about geological characteristics of mineral deposits of the world called Data
Metallogenica (DM). In 1999 Data Metallogenica transferred to Australia and was installed at the Australian Mineral Foundation (AMF) in Glenside (suburb of Adelaide, South Australia) under the sponsorship of more than seventy mining companies and some government organizations (Fig. 4). Funds were raised and project managed by Amira International of Melbourne who became the sole owner of DM after AMF liquidation at the end of 2001. DM website (www.datametallogenica.com) has been on line since 2002 with full access open to subscribers. General public can access an extensive preview and a list of almost 4000 entries (mainly ore deposits, each represented by one or more Lithotheque plates) in 80 plus countries. Following the change of building ownership the DM physical collection has been placed into a temporary storage to be relocated into new premises in the near future, hence it is not presently accessible. The DM website operated by Amira continues. A new DM version, Data Metallogenica Original (DMO) has been initiated by Peter Laznicka with the objective to return to the core DM mission with emphasis on continuing worldwide sampling, physical collection growth, and continuous update of the past DM documentation (visit www.totalmetallogeny.com/DataMet; www.metallogenicalaznicka,com).

The backbone of Data Metallogenica is an extensive global collection of Lithotheque (LT) plates. In the original, library-like configuration. Lithotheque plates are held in library-like, purpose made stacks, suitable for browsing and instant acquisition. Most plates are stored vertically, like books, whereas a minority of plates with friable or unconsolidated samples are stored horizontally. The DM physical collection contains additional components, the photographic images of which are included in the website. These are: a library of 

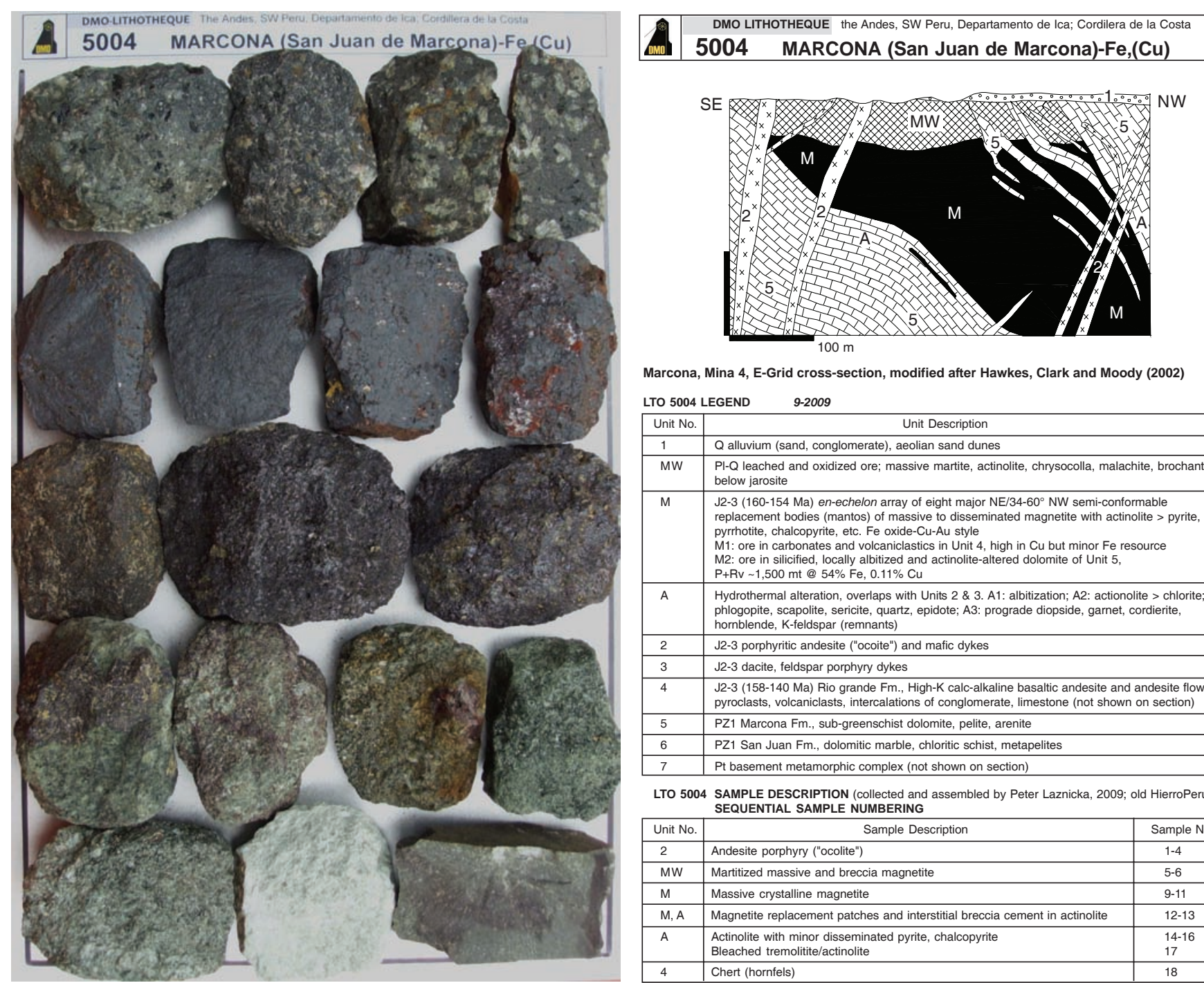

Marcona, Mina 4, E-Grid cross-section, modified after Hawkes, Clark and Moody (2002) LTO 5004 LEGEND $\quad 9-2009$

\begin{tabular}{|c|l|}
\hline Unit No. & \multicolumn{1}{|c|}{ Unit Description } \\
\hline 1 & Q alluvium (sand, conglomerate), aeolian sand dunes \\
\hline MW & $\begin{array}{l}\text { P1-Q leached and oxidized ore; massive martite, actinolite, chrysocolla, malachite, brochantite, } \\
\text { below jarosite }\end{array}$ \\
\hline M & $\begin{array}{l}\text { J2-3 (160-154 Ma) en-echelon array of eight major NE/34-60 } \mathrm{NW} \text { semi-conformable } \\
\text { replacement bodies (mantos) of massive to disseminated magnetite with actinolite > pyrite, } \\
\text { pyrhotite, chalcopyrite, etc. Fe oxide-Cu-Au style } \\
\text { M1: ore in carbonates and volcaniclastics in Unit 4, high in Cu but minor Fe resource } \\
\text { M2: ore in silicified, locally albitized and actinolite-altered dolomite of Unit 5, } \\
\text { P+Rv 1,500 mt @ 54\% Fe, 0.11\% Cu }\end{array}$ \\
\hline A & $\begin{array}{l}\text { Hydrothermal alteration, overlaps with Units 2 \& 3. A1: albitization; A2: actionolite > chlorite; } \\
\text { phlogopite, scapolite, sericite, quartz, epidote; A3: prograde diopside, garnet, cordierite, } \\
\text { hornblende, K-feldspar (remnants) }\end{array}$ \\
\hline 2 & J2-3 porphyritic andesite ("ocoite") and mafic dykes \\
\hline 3 & J2-3 dacite, feldspar porphyry dykes \\
\hline 4 & $\begin{array}{l}\text { J2-3 (158-140 Ma) Rio grande Fm., High-K calc-alkaline basaltic andesite and andesite flows, } \\
\text { pyroclasts, volcaniclasts, intercalations of conglomerate, limestone (not shown on section) }\end{array}$ \\
\hline 5 & PZ1 Marcona Fm., sub-greenschist dolomite, pelite, arenite \\
\hline 6 & PZ1 San Juan Fm., dolomitic marble, chloritic schist, metapelites \\
\hline 7 & Pt basement metamorphic complex (not shown on section) \\
\hline
\end{tabular}

LTO 5004 SAMPLE DESCRIPTION (collected and assembled by Peter Laznicka, 2009; old HierroPeru pit) SEQUENTIAL SAMPLE NUMBERING
SARembled by Peter Laznicka, 2009; old HierroPeru pit)

\begin{tabular}{|l|l|c|}
\hline Unit No. & \multicolumn{1}{|c|}{ Sample Description } & Sample No \\
\hline 2 & Andesite porphyry ("ocolite") & $1-4$ \\
\hline MW & Martitized massive and breccia magnetite & $5-6$ \\
\hline M & Massive crystalline magnetite & $9-11$ \\
\hline M, A & Magnetite replacement patches and interstitial breccia cement in actinolite & $12-13$ \\
\hline A & Actinolite with minor disseminated pyrite, chalcopyrite & $14-16$ \\
& Bleached tremolitite/actinolite & 17 \\
\hline 4 & Chert (hornfels) & 18 \\
\hline
\end{tabular}

Figure 2. A typical Lithotheque plate (Marcona-Fe, Peru) and its explanation sheet (legend). Samples are arranged chronologically: the top row contains post-mineralization porphyry dikes, underneath are samples of oxidized (martite) and primary ore (magnetite), gangues (actinolite), alterations, and host rocks. The explanation sheet includes a generalized cross-section (modified from the literature) that shows numbered lithologic units (from youngest to oldest), mineralizations (M=hypogene ore; $M W=$ weathered ore) and hydrothermal alterations (A; read also Table 1). These units, in general, are characterized in the upper table on the explanation sheet, whereas the lower table describes the actual samples keyed to corresponding units.

folders where each LT plate is accompanied by field photos, slides, notes, maps and literature reprints; Macrotheque, a collection of hand specimens, many with thin and polished sections, organized by lithotectonic associations; a collection of thin and polished sections; a collection of rock/ore chips and offcuts remaining after Lithotheque preparation, available for wet analysis. There is a small archive of reprints, notes and photos organized by geological environments and lithologic associations, and a library. During the five years that the DM physical collection had been accessible in its purpose-equipped showroom, visitors were welcome to come over, examine the material, conduct nondestructive tests and receive guidance from resident experts.

\section{Samples-assisted integration of knowledge about global metallogeny}

During its brief six years of active existence in Adelaide, Data
Metallogenica (DM) physical collection grew to some 3500 Lithotheque (LT) plates representing deposits in 75 countries (presently there are some 4000 LT's from $\sim 80$ countries) so it covers the world's practical metallogeny in a greater detail than any other product in existence. DM can provide the geologist with a set of images from the various types of world's mineral deposits that can be identified in the field or drill core and interpreted by analogy. The Adelaide DM centre was a one-stop place where industry and government professionals could, in a short time, peruse and compare an enormous amount of practical information in the form of geological materials, literature reprints, original field notes and photos, to gain inspiration and formulate new ideas directly applicable to mineral exploration. In DM, the State of South Australia is presently represented by 210 Lithotheque plates, about $5 \%$ of the DM's total (Fig.5), and is the single best covered jurisdiction globally (Australia is represented by 1251 Lithotheques, Canada by 810 , the United States by 481); many countries, like Russia, are seriously 
\begin{tabular}{|r|ll|}
\hline DWO & \multicolumn{2}{|c|}{ DMO- LITHOTHEQUE Geotectonic Province/System, Country, Geological subdivisions } \\
OWO & 0000 number Locality (and subdivisions)-commodities \\
\hline
\end{tabular}

Generalized (simplified) cross-section (or map, stratigraphic column) of Locality, usually modified published graphic. Mineralization (M) is shown in solid black, or as outline. Geological units are numbered (usually from youngest to oldest) and explained below.

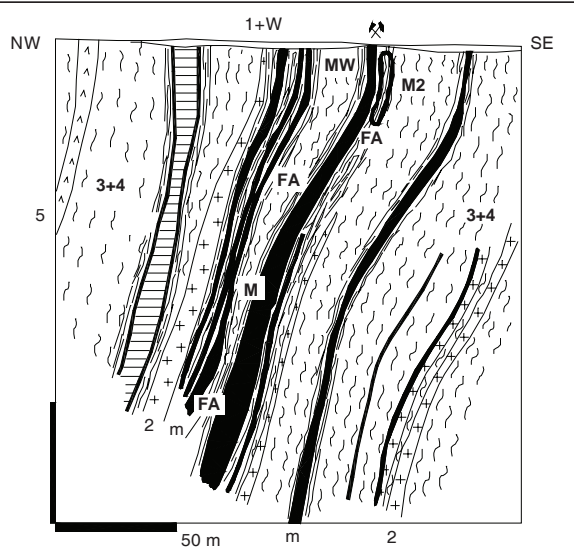

Locality 0000, diagrammatic cross-section based on (reference)

LTO 0000 LEGEND 4-2008 (date of last revision)

\begin{tabular}{|l|c|}
\hline Unit No & \multicolumn{1}{|c|}{ Unit Description } \\
\hline 1 & Geological age (letter code [read below] or absolute age in Ma/Ga); Unit name and description \\
\hline 2,3, etc. & \\
\hline
\end{tabular}

LTO 0000 SAMPLE DESCRIPTION (collected and assembled by....., year). SAMPLE NUMBERING (GRID numbering where each cell on sample plate has a number, even if empty. Five rows of four columns: 1,2,3,4; 5,6,7,8; 9,10,11,12; 13,14,15,16; 17,18,19,20).

SEQUENTIAL numbering where each sample has its number, regardless of position; this is used mostly with oversize samples).

\begin{tabular}{|l|c|c|}
\hline Unit No & Sample Description & Sample No \\
\hline 1 (unit) & Brief description of the Lithotheque sample, numbered in right column & e.g. 1,2 \\
\hline 2,3, etc. & & \\
\hline
\end{tabular}

TYPES OF UNITS
$1,2,3, \ldots$ geological (stratigraphic, lithologic) units hosting mineralization, and locally associated
M mineralizations (e.g. metallic ores) in general and usually "primary". If more than one, use M1, M2, M3.
MW weathering-modified ("secondary") ores in oxidation \& secondary sulfide zones, gossans, etc.
MS resedimented ores (in relation to the "primary" M's)
MX anthropogenic metal-bearing objects, e.g. tailings, dumps
MA mineralization and (usually hydrothermal) alteration treated jointly
F "fault rocks" filling deformation structures (faults, shears), e.g. mylonite, phyllonite, fault breccia, gouge
FA altered (usually hydrothermally) fault rocks
FM mineralized fault rocks
Bx breccias (all genetic varieties)
A (wall rock and regional) alterations (usually hydrothermal); if more than one, A1, A2, A3...
$1 \mathrm{~A}, 2 \mathrm{~A}$, etc., altered geological units
W weathering (supergene modification) of units; e.g. 1W, 2W, 3W. Weathering varieties: W1, W2, W3...
mt thermal (contact) metamorphism superimposed on units

CODES OF GEOLOGICAL TIME ABBREVIATION

\begin{tabular}{|l|l|c|}
\hline $\begin{array}{l}\text { Stratigraphic } \\
\text { division }\end{array}$ & $\begin{array}{l}\text { Age Ma } \\
\text { (from) }\end{array}$ & Abbreviation \\
\hline Phanerozoic & $570(540)$ & $\mathrm{PhZ}$ \\
Cainozoic & $65(64.4)$ & $\mathrm{CZ}$ \\
Quaternary & 1.6 & $\mathrm{Q}$ \\
Tertiary & $65(64.4)$ & $\mathrm{T}$ \\
Pliocene & $5.3(4.8)$ & $\mathrm{PI}$ \\
Miocene & $23(23.7)$ & $\mathrm{Mi}$ \\
Oligocene & 36.5 & $\mathrm{OI}$ \\
Eocene & $53(57.8)$ & Eo \\
Paleocene & $65(64.4)$ & $\mathrm{Pc}$ \\
Mesozoic & 250 & $\mathrm{MZ}$ \\
Cretaceous & 135 (140) & Cr \\
Jurassic & 205 & $\mathrm{~J}$ \\
Triassic & 250 & Tr \\
\hline 3 (e.g. Pe3) & \multicolumn{2}{|l}{ upper (late) (e.g. Upper Permian) } \\
2 (e.g. Pe2) & middle (e.g. Middle Permian) \\
1 (e.g. Pe1) & lower (early) (e.g. Lower Permian)
\end{tabular}

\begin{tabular}{|l|l|c|}
\hline $\begin{array}{l}\text { Stratigraphic } \\
\text { division }\end{array}$ & $\begin{array}{l}\text { Age Ma } \\
\text { (from) }\end{array}$ & Abbreviaiton \\
\hline Paleozoic & $570(540)$ & $\mathrm{PZ}$ \\
Permian & 290 & $\mathrm{Pe}$ \\
Carboniferous & 355 & $\mathrm{Cb}$ \\
Devonian & 410 & $\mathrm{D}$ \\
Silurian & 438 & $\mathrm{~S}$ \\
Ordovician & 510 & $\mathrm{Or}$ \\
Cambrian & $570(540)$ & $\mathrm{Cm}$ \\
Precambrian & $\sim 4200$ & $\mathrm{PCm}$ \\
Proterozoic & 2500 & $\mathrm{Pt}$ \\
Neoproterozoic & 1000 & $\mathrm{~Np}$ \\
Mesoproterozoic & 160 & $\mathrm{Mp}$ \\
Paleoproterozoic & 2500 & $\mathrm{Pp}$ \\
Archean & $\sim 4200$ & $\mathrm{Ar}$ \\
\hline
\end{tabular}

Figure 3. Template of the explanation sheet ("legend") that accompanies each Lithotheque plate (Source: Peter Laznicka, 2008). 


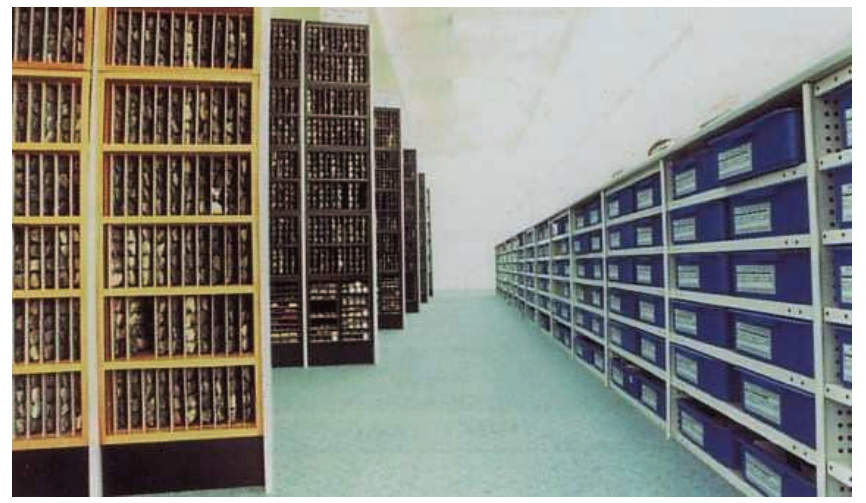

Figure. 4. Data Metallogenica showroom in Adelaide, in the 1999. 2005 period. The majority of Lithotheque plates was stored in vertical position, like books, for easy browsing and instant accessibility. A minority (shown at the bottom of stacks) are horizontally stored plates containing friable samples. Drawers on the right hand side contain Macrotheque, a complementary collection of loose hand samples.

underrepresented, a consequence of insufficient funding and restrictions on transport of geological samples across borders (Fig. 6). Portion of the South Australian DM on-line can be accessed for free on the government SARIG website (www.sarig.pir.sa.gov.au) where it complements other information about the mineral prospectivity of the State.

Although Data Metallogenica (DM) is a stand-alone knowledge system, it is eminently suitable for integration into a variety of media and projects that depend on and disseminate geological knowledge on the global basis. In the book "Giant Metallic Deposits-Future Sources of Industrial Metals" (Laznicka, 2006) about two-thirds of the $\sim 700$ ore deposits and districts have been sampled and are a part of DM, so a book reader who is also a DM subscriber can instantly extend the information search to visualize the rock and ore lithology in vivid color, and retrieve many additional information not available in published literature or on internet. Those keen enough can

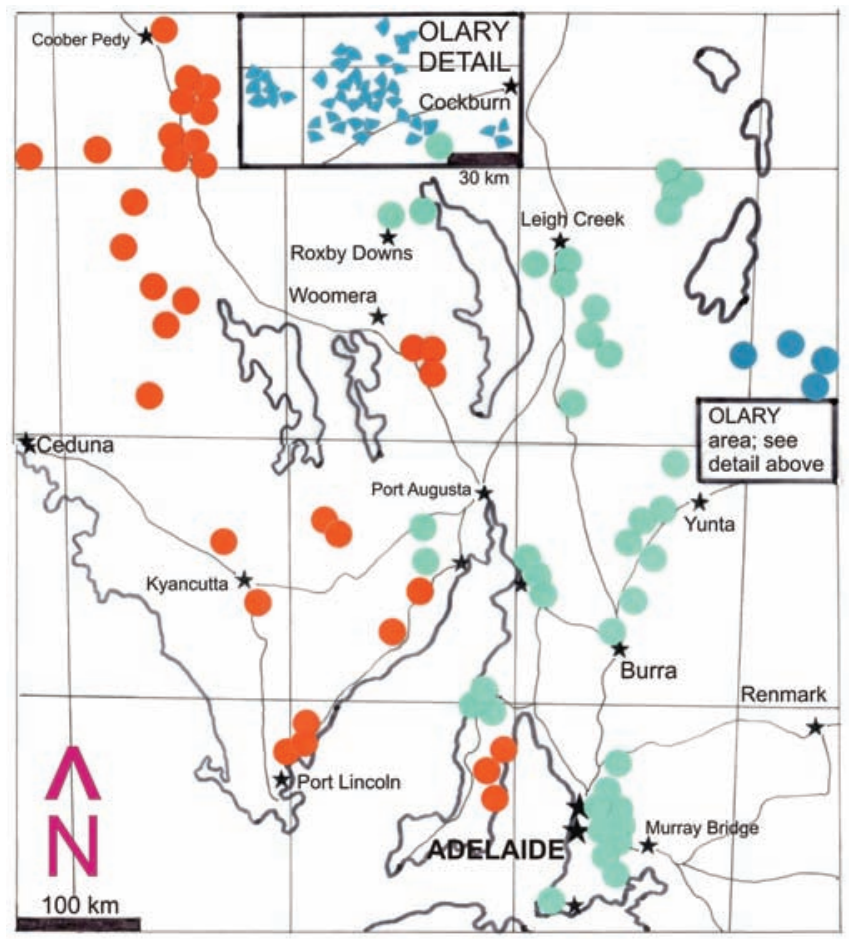

Figure 5. A map of Lithotheque sets representing about 200 localities in the State of South Australia, the most densely covered jurisdiction.

eventually visit the actual collection, perform comparisons and conduct non-destructive testing.

Ore deposit types can be visualized and compared using Lithotheque displays to determine membership of a locality in a certain "ore type" or "family" (like the IOCG, that is Iron Oxide Copper Gold "family"; Hitzman et al., 1992) and to identify characteristics of member deposits substantially departing from those in the ideal model (Fig. 7). This helps to filter out irrelevant characteristics of this "family", remove deposits that do not belong, and strengthen the important features on which to concentrate in exploration. The geo-samples supported technique of objective, primary data recording and presentation provides a credible base for mineral assessments, prognoses and exploration target generation. Metallogeny of a local area can be visualized and compared using assembly of Lithotheque plates keyed to ore deposits and geological associations on a map (Fig. 8). In one example from the Asir Province in the Kingdom of Saudi Arabia (Fig. 9) the Lithotheque sample plates from selected ore deposits and their cross-sections are matched with a set of ore deposit models, the lithotectonic setting of
Figure 6. World's map of Lithotheque localities (mostly mineral deposits) shown by red dots, as of 2009. Note the uneven coverage, a consequence of limited funding and difficulties to take samples out of some countries. The present population of 4000 sets in the Data Metallogenica collection should gradually increase. 

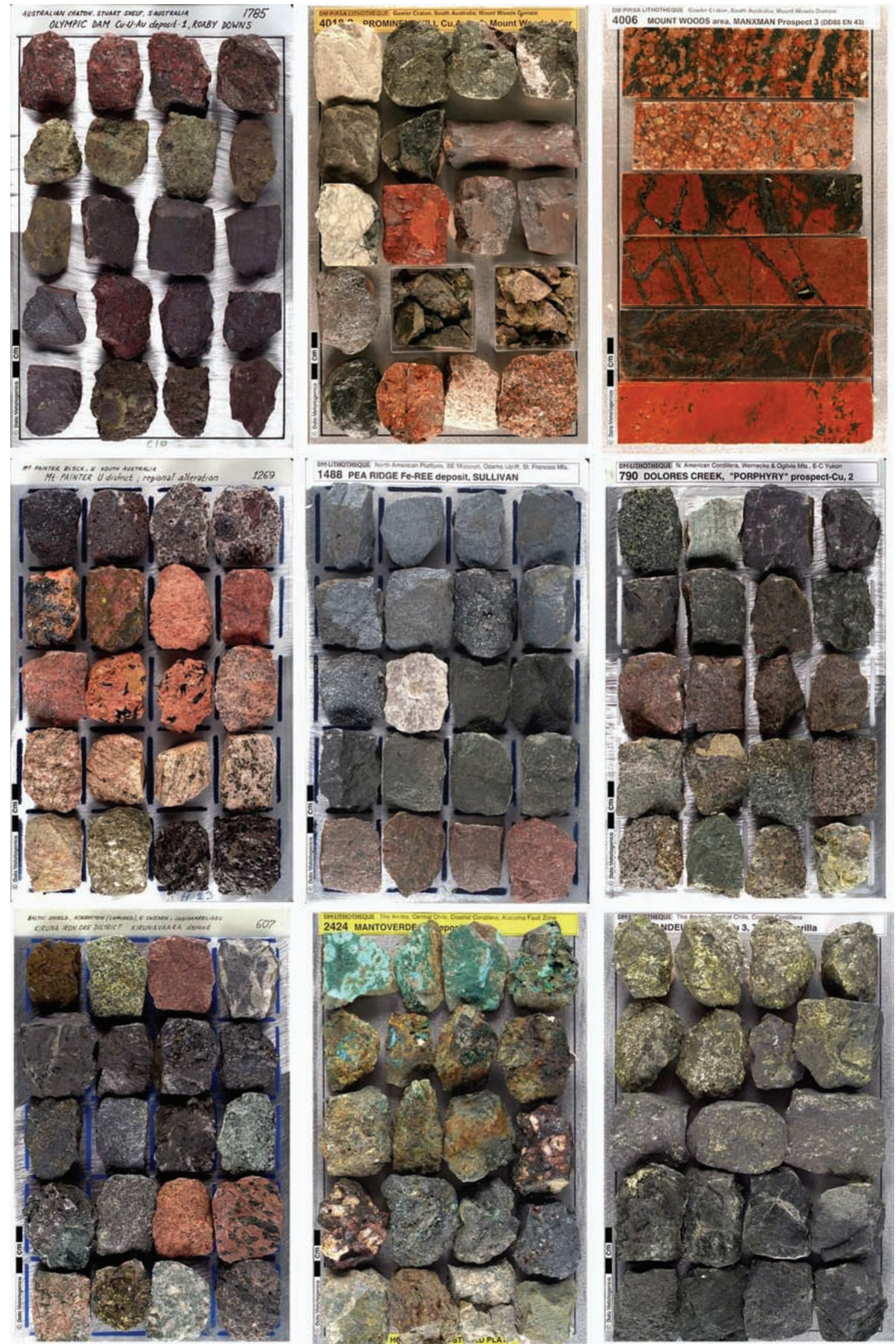

Figure 7. A set of nine selected Lithotheque plates representing various deposits included in the IOCG "family" of ore deposits. Comparison of the actual material reveals substantial lithologic variations, not apparent from literature descriptions. From left to right, then down: 1, Olympic Dam; 2, Prominent Hill; 3, Manxman; 4, Mount Painter, all in South Australia; 5, Pea Ridge, Missouri; 6, Dolores Creek, Yukon; 7, Kiruna, Sweden; 8, Mantoverde and 9, Candelaria, both in Chile. 


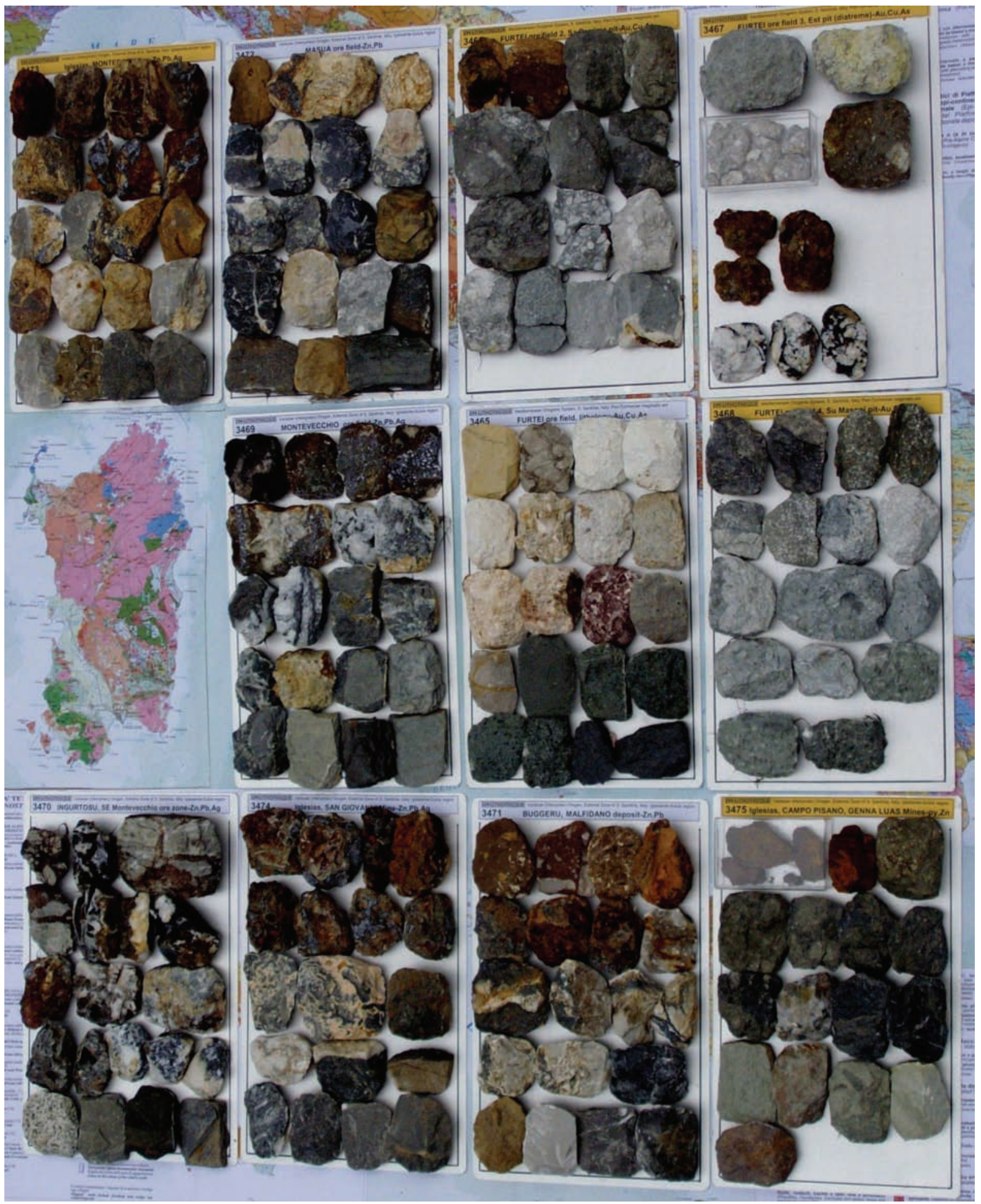

Figure 8. Assembly of Lithotheque plates representing lithology and ores of selected deposits in the Iglesiente and Arbus regions of southern Sardinia, Italy.

which is shown in a global "geosite" cartoon appropriate for the local area (Laznicka, 2001). The global standards of deposits, ore type models and "geosites" ("plays", rock relation diagrams, lithotectonic associations) can then be compared with geology of the target area in order to select the closest match. At the above figure the U.S. Geological Survey mineral deposit models (Cox and Singer, eds., 1986) have been applied, although a better fitting models could be created for any geological setting.

\section{Adoption of the Lithotheque/Data Metallogenica format as a means of international cooperation and exchange: a proposal}

Many products in our daily lives like paper and film formats are internationally standardized. Lithotheque, after nearly forty years of experimentation, is now an established design that preserves, stores 


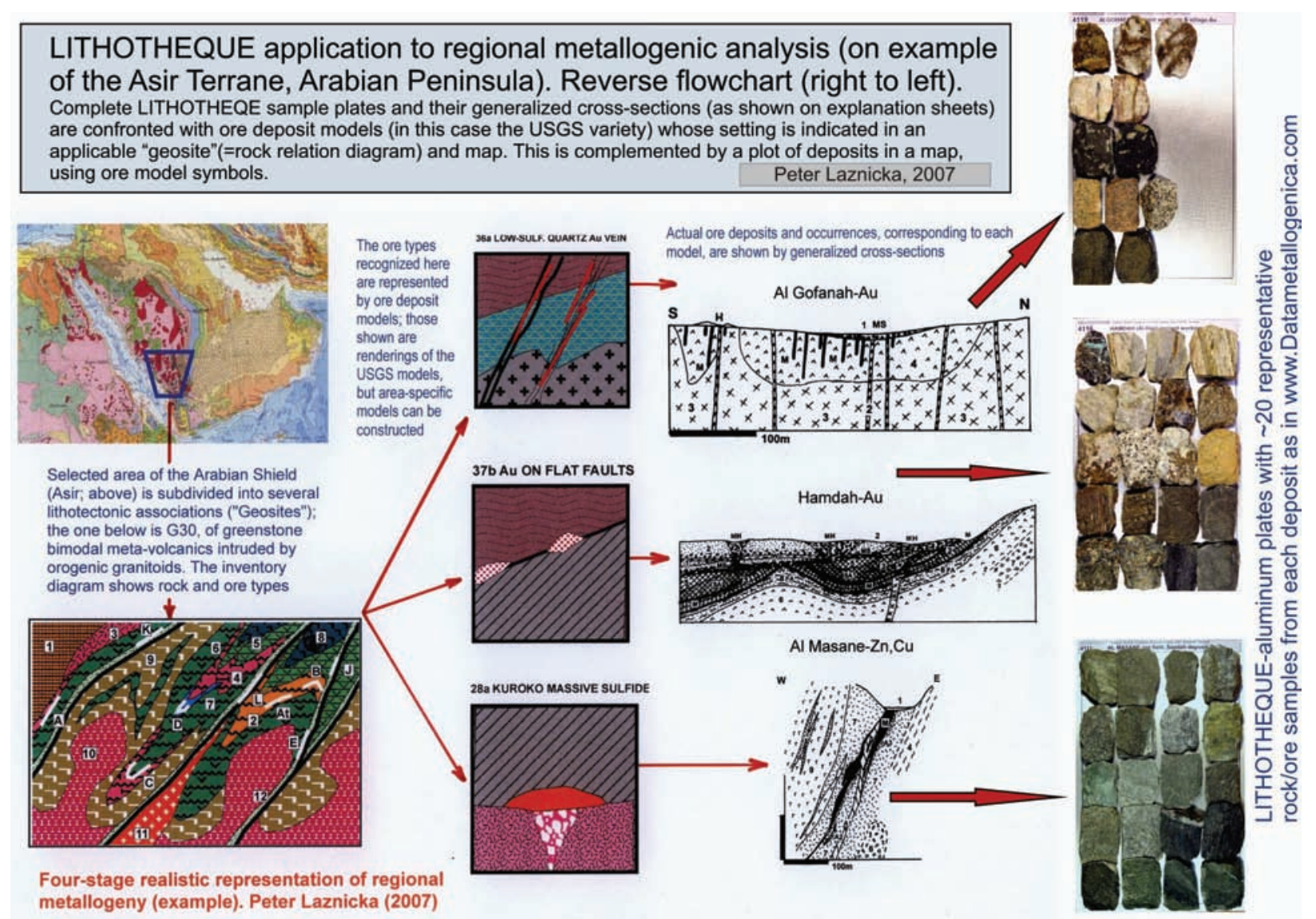

Figure 9. Application of miniaturized geological sample sets for regional metallogenic analysis (Asir Province, Kingdom of Saudi Arabia). Three gold deposits represented by Lithotheque plates (right column) with cross-sections (second column from right) are confronted with their closest U.S. Geological Survey Mineral Deposit Models (Cox and Singer, eds., 1986) which, in turn, appear in a "Geosite" (inventory diagram of prevalent rock associations and ores) of Laznicka (2001).

and disseminates non-controversial and permanent geological information. It is a product that is being actively used. Although preparation of rigid plates with permanently attached geological samples is not a new technique, Lithotheque (LT) and Data Metallogenica (DM) applications have achieved critical weight and maturity and they have the potential to become a means of global cooperation and exchange if their parameters (style, organization, dimensions) are uniformly adopted.

Presently, the privately held Data Metallogenica (DM) and its extension DMOriginal (DMO) comprise close to 4000 Lithotheque sets (some 70,000 miniaturized samples) from about 85 countries of the world. Although this system and collection contain examples of the majority of recognized ore deposit types, DM is far from complete and it is estimated that some 100,000 mineralized localities worldwide should eventually be included. $90 \%$ of the existing DMO entries have been sampled and compiled by a single person and to eventually approach the proposed target, international cooperation is required. Any regional (country, state, territory, geological division, mineralized province) organization, like geological survey, should be able to assemble Lithotheque-style records from geological sites (including mineral deposits) in their jurisdiction. Such physical collection could be held locally and open to visitors, the photographic images would reside in a website with a worldwide audience. Sample sets, loose or attached to plates, with documentation, collected and formatted to conform to the LT standard, could be internationally traded and exchanged. This would provide an opportunity to gradually build, very inexpensively, collections of samples from the various world localities for local use, for comparison and education which, at present, is a difficult task to accomplish especially by countries and organizations with limited means. An international Lithotheque effort would be a great equalizer where any country or territory, regardless of their degree of development, affluence and research capability, could make a unique contribution to global understanding as an equal and to retain the product of their effort, the national Lithotheque collection, at home. A global network of such collections searchable on-line would provide the professional community and students with images of the various types of ores and geological settings that can be identified in the field or drill core and interpreted by analogy.

\section{Acknowledgement}

I am grateful to Prof. Harald Dill for alerting me about the existence of the Deutches Naturstein-Archiv.

\section{References}

Cox, D.P., and Singer, D.A., (editors), 1986, Mineral Deposit Models:

U.S. Geological Survey Bulletin 1693.

Hitzman, M.W., Oreskes, N., and Einaudi, M.T., 1992, Geological 
characteristics and tectonic setting of Proterozoic iron oxide $(\mathrm{Cu}-$ U-Au-REE) deposits: Precambrian Research, v. 58, pp. 241-287.

Keeling, J., Mauger, A., and Huntington, J., 2004. Spectral core logger update-preliminary results from the Barns gold prospect: MESA Journal, v. 23, Adelaide, pp. 32-36.

Kyle, J.R., and Ketcham, R.A., 2003, In situ distribution of gold in ores using high-resolution X-ray computed tomography: Economic Geology, v. 98, pp. 1697-1701.

Laznicka, P., 2001, Total Metallogeny-Geosites (book and poster). Australian Mineral Foundation, Adelaide, 720 p.

Laznicka, P., 2006, Giant Metallic Deposits, Future Sources of Industrial Metals: Springer-Verlag, Heidelberg, 732 p.

Marrocchino, E., et al., 2008, Stone materials archives: the case study of the Riminaldi's Lithotheque in Ferrara, Italy. Poster, 33th International Geological Congress, Oslo.

Mauger, A.J., 2008, National Virtual core library-South Australian commitment: MESA Journal, v.50, Adelaide, September 2008, pp. 22-23.

Mikulic, D.G., and Kluessendorf, J., 2002, The crisis in geological collections. Geotimes, June 2002.

National Academy of Sciences, 2002, Geoscience data and collections: National resources in peril. National Academies Press, http:// www.nap.edu/books/0309083419/html/.

Simpson, A., 2003, The plight of geological collections in the Australian tertiary education system: Museologia (Lisbon), v.3, pp. 3744.

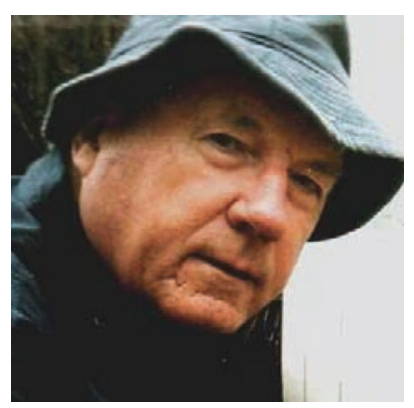

Peter Laznicka graduated from Charles University (B.Sc.) and the University of Manitoba (M.Sc., Ph.D.), where he also spent 27 years as Professor of Geology and Mineral Resources. In 1999 he re-located to Australia to reestablish Data Metallogenica (DM) in a new home, a knowledge system about world's mineral deposits based on a large collection of miniaturized sample sets; DM is presently operated, on-line, by Amira International. He practices international consulting, lecturing and growing Data Metallogenica Original out of Adelaide.

\title{
CALL FOR PAPERS
}

Episodes is a quarterly science and news journal of the International Union of Geological Sciences (IUGS). It focuses on the publication of results of scientific research and other information addressing issues of interest to the global Earth science community. Special emphasis is given to topics involving geological aspects of population growth and economic development and their resulting impacts on or implications for society. As the principal publication of the IUGS, Episodes also carries information about IUGS scientific programs and activities to the extent necessary to communicate effectively with the worldwide IUGS constituency.

Contributions of the following types of manuscripts are solicited:

- Review papers

- News and views
- Conference reports

- Book reviews

- Information on training courses (especially those geared to participants from developing countries)

- Noteworthy new publications, including national or regional geological maps

Episodes also invites photos or other images for the front cover. Photos must be of high technical quality and tell an interesting geological story. A color transparency and one color print (at least $9 \mathrm{~cm} \times 12.6 \mathrm{~cm}$ ) are required for submission, which should be supplemented with a short explanatory paragraph (no more than 100 words).

Please address all contributions to:

\author{
Dr. M. Jayananda - Editor \\ Episodes \\ Geological Society of India \\ No.63, $12^{\text {th }}$ Cross, Basappa Layout \\ Gavipuram P.O., P.O. Box 1922 \\ Bangalore - 560 019, INDIA \\ Phone: +91-080-22422943; Telefax: +91-80-26613352 \\ Email: episodes.editor@gmail.com
}

